OPEN ACCESS

Edited by:

Demet Demirkol,

Istanbul University, Turkey

Reviewed by:

Genny Raffaeli,

IRCCS Ca 'Granda Foundation

Maggiore Policlinico Hospital, Italy

Şule Ünal Cangül,

Hacettepe University, Turkey

${ }^{*}$ Correspondence:

Holger Hauch

holger.hauch@

paediat.med.uni-giessen.de

TORCID:

Holger Hauch

orcid.org/0000-0001-6454-7783

Susanne Skrzypek

orcid.org/0000-0002-1162-8544

Wilhelm Woessmann

orcid.org/0000-0002-6315-0888

Kai Lehmberg

orcid.org/0000-0003-2365-4341

Stephan Eh

orcid.org/0000-0002-9265-2721

Carsten Speckmann

orcid.org/0000-0002-6217-1556

Emmanuel Schneck

orcid.org/0000-0003-0565-1550

Dieter Koerholz

orcid.org/0000-0002-8205-8665

Christian Jux

orcid.org/0000-0003-2143-5153

Christoph Neuhäuser

orcid.org/0000-0002-0666-0996

Specialty section:

This article was submitted to

Pediatric Critical Care,

a section of the journal

Frontiers in Pediatrics

Received: 27 April 2020

Accepted: 29 September 2020

Published: 30 October 2020

Citation:

Hauch H, Skrzypek S, Woessmann W Lehmberg K, EhI S, Speckmann C Schneck E, Koerholz D, Jux C and Neuhäuser $C$ (2020)

Tuberculosis-Associated HLH in an 8-Month-Old Infant: A Case Report and Review. Front. Pediatr. 8:556155

doi: 10.3389/fped.2020.556155

\section{Tuberculosis-Associated HLH in an 8-Month-Old Infant: A Case Report and Review}

\author{
Holger Hauch ${ }^{1 *}$, Susanne Skrzypek ${ }^{2 \dagger}$, Wilhelm Woessmann ${ }^{3 \dagger}$, Kai Lehmberg ${ }^{3 \dagger}$, \\ Stephan Ehl ${ }^{4,5 \dagger}$, Carsten Speckmann ${ }^{4,5 \dagger}$, Emmanuel Schneck ${ }^{6 \dagger}$, Dieter Koerholz ${ }^{1 \dagger}$, \\ Christian Jux $^{2 \dagger}$ and Christoph Neuhäuser ${ }^{2 \dagger}$ \\ ${ }^{1}$ Department of Pediatric Hematology and Oncology, University Children's Hospital of Giessen, Giessen, Germany, \\ ${ }^{2}$ Department of Pediatric Cardiology and Intensive Care, University Children's Hospital Giessen, Giessen, Germany, ${ }^{3}$ Division \\ of Pediatric Stem Cell Transplantation, University Children's Hospital Hamburg, UKE, Hamburg, Germany, ${ }^{4}$ Center for \\ Chronic Immunodeficiency, Institute for Immunodeficiency, Medical Center-University of Freiburg, Freiburg, Germany, \\ ${ }^{5}$ Center of Pediatrics and Adolescent Medicine, Medical Center-University of Freiburg, Freiburg, Germany, ${ }^{6}$ Department of \\ Anesthesiology and Intensive Care Medicine, University Children's Hospital Giessen, Giessen, Germany
}

Hemophagocytic lymphohistiocytosis $(H L H)$ is a rare immunological disease, which can be mistaken for sepsis easily. Among the infectious causes that may trigger secondary $\mathrm{HLH}$, tuberculosis (TBC), a rather rare pathogen nowadays, is typical. To our knowledge, this is the first case report of an infant suffering from TBC-associated HLH-induced acute respiratory failure who was treated successfully using extracorporeal membrane oxygenation. An 8-month-old boy with fever (over the last 8 wk) and pancytopenia was transferred to our institution with acute respiratory failure and for extracorporeal membrane oxygenation therapy. Bone marrow biopsy revealed hemophagocytosis. Immunological work-up for familial HLH was negative. In a desperate search for the cause of secondary $\mathrm{HLH}$, an interferon-gamma release assay for TBC returned positive. However, microscopy for acid-fast bacteria as well as polymerase chain reaction for TBC were initially negative. Despite this, the child was treated with tuberculostatic therapy. TBC was finally confirmed. The child remained on extracorporeal membrane oxygenation for $28 \mathrm{~d}$. Further work-up showed typical lesions of disseminated TBC. The mother was identified as the source of TBC. The boy presents with mild sequelae (fine motor skills). In infants with suspected septicemia, TBC should be considered as differential diagnosis even if the results are initially negative.

Keywords: tuberculosis, infant, hemophagocytic lymphohistiocytosis, lung failure, extracorporeal membrane oxygenation, ECMO, case report

\section{INTRODUCTION}

Hemophagocytic lymphohistiocytosis (HLH) is a rare syndrome, characterized by a highly stimulated but ineffective immune response. The mechanism involves an inherited or acquired defect in the handling of antigenic factors (infectious, cancerous, or autoimmune) that leads to a severe systemic inflammatory process due to T-lymphocyte proliferation, cytokine overproduction, and massive macrophage activation $(1,2)$. The associated pancytopenia results from hypercytokinemia and hemophagocytosis that develops within the bone marrow, whereas 
the subsequent organ dysfunction is caused by tissue infiltration of active immune cells. The main symptoms of HLH are prolonged fever, neutro- and thrombocytopenia, hepatosplenomegaly, and conspicuous laboratory values, such as low fibrinogen and elevated levels of ferritin, triglycerides and sCD25 (3).

We report here the first case of secondary $\mathrm{HLH}$ in an infant with miliary tuberculosis (TBC) and acute respiratory failure, who survived following extracorporeal membrane oxygenation (ECMO) therapy. The purpose of this report is to improve recognition of this uncommon, life-threatening condition and to avoid possible pitfalls. In addition, a literature search (performed for "hemophagocytic histiocytosis," "haemophagocytic lymphohistiocytosis," "histiocytosis," "hemphagocytic syndrome," "haemophagocytic syndrome," "histiocytic hemophagocytosis," "histiocytic haemophagocytosis," "children," "infant," "TBC," "Mycobacterium tuberculosis," "acute respiratory distress syndrome," and "ECMO," including databases: PubMed, EMBASE, Cochrane Library, searching period 2000-2009) provided historical and current information on this topic for our discussion on the possible pitfalls of missed diagnosis of this condition.

\section{CASE DESCRIPTION}

\section{Case History}

A previously healthy 8-month-old boy presented to an outside hospital with high fever and cough since weeks. Because of C-reactive protein test showing elevated level and unspecific infiltration detected on chest $\mathrm{x}$-ray, the child had been administered antibiotic therapy, consisting of beta-lactams and glycopeptides. Beside reduced levels of hemoglobin (5.6-7.8 mmol/L; normal range: $6.3-7.8 \mathrm{mmol} / \mathrm{L}$ ) and platelets $\left(90-125 \times 10^{9} / \mathrm{L}\right.$; normal range: $206.000-445.000$ $\times 10^{9} / \mathrm{L}$ ), laboratory results were otherwise unremarkable. Results of infectious work-up [blood, cerebral spinal fluid and urine cultures, as well as polymerase chain reaction (PCR) for respiratory viruses and pathogens for atypical pneumonia] remained negative. Because of the persisting fever, the child was transferred to three other hospitals, recently to a tertiary care hospital, where he was evaluated for immunodeficiency. Bronchoscopy with bronchoalveolar lavage was carried out under general anesthesia with endotracheal intubation because of declining general condition. Since respiratory functions had deteriorated dramatically, the child was transferred to our institution for ECMO-support (at 4 wk after first presentation). No definite diagnosis existed to that time.

Medical history taking with the parents revealed an uneventful pregnancy and birth in Germany. The parents originated from the Balkan peninsula. The patient was the first child and the parents claimed to be healthy.

\section{Physical Examination}

The child was unconscious due to deep analgo-sedation (Glasgow coma score of 3/15). The vesical temperature was $40.3^{\circ} \mathrm{C}$, heart rate was $142 \mathrm{bpm}$, blood pressure was $82 / 44$
$\mathrm{mmHg}$ (under continuous infusion with epinephrine 2.0 $\mathrm{mcg} / \mathrm{kg} / \mathrm{min}$ ), weight was $7.9 \mathrm{~kg}$ (15th percentile, World Health Organization scale), length was $70 \mathrm{~cm}$ (30th percentile, World Health Organization scale), $\mathrm{SpO}_{2}$ was $70 \%$. The pressurecontrolled ventilation maintained peak inspiratory pressure of $60 \mathrm{~cm} \mathrm{H}_{2} \mathrm{O}$, positive end-expiratory pressure of $12 \mathrm{~cm} \mathrm{H} \mathrm{H}_{2} \mathrm{O}$, $\mathrm{FiO}_{2}$ of 1.0 , frequency of $40 \mathrm{pm}$, and Horovitz quotient of 30. The spleen was $5 \mathrm{~cm}$ and the liver $6 \mathrm{~cm}$, palpable in midclavicular lines. Our first clinical impression was that of a systemic infection with severe acute respiratory failure and unexplained lymphoproliferation.

\section{Laboratory Examinations}

Blood analysis revealed pancytopenia (hemoglobin: 4.3 $\mathrm{mmol} / \mathrm{L}$; leucocytes: $2.600 \times 10^{9} / \mathrm{L}$; neutrophils: $800 \times$ $10^{9} / \mathrm{L}$; platelets: $\left.32.000 \times 10^{9} / \mathrm{L}\right)$, elevated levels of C-reactive protein (194 $\mathrm{mg} / \mathrm{L}$; normal range: $<5 \mathrm{mg} / \mathrm{L})$, ferritin $(1,020 \mu \mathrm{g} / \mathrm{L}$; normal range: $14-103 \mu \mathrm{g} / \mathrm{L})$, triglycerides (3.58 $\mathrm{mmol} / \mathrm{L}$ normal range: $0.4-1.6 \mathrm{mmol} / \mathrm{L}$ ), and soluble interleukin-2 receptor $(30,247 \mathrm{U} / \mathrm{mL}$; normal range: $158-$ $623 \mathrm{U} / \mathrm{mL}$ ). Analyses of arterial blood gases showed $\mathrm{pH}$ of 6.9, $\mathrm{pCO}_{2}$ of $93 \mathrm{mmHg}, \mathrm{pO}_{2}$ of $30 \mathrm{mmHg}$, and base-excess of $-11.1 \mathrm{mmol} / \mathrm{L}$.

\section{Imaging Studies and Further Examinations}

Initial imaging with $\mathrm{x}$-ray showed a "white lung" (Figure 1A) and with ultrasound showed hepato- and splenomegaly. Further imaging work-up, with either computed tomography or magnetic resonance imaging, could not be performed because of the instable situation.

Bone marrow biopsy showed a distinct hemophagocytosis upon cytologic evaluation (Figure 1B). The lymphocyte population consisted of $\mathrm{CD}^{+}$of $1,358 \times 10^{9} / \mathrm{L}, \mathrm{CD} 4^{+}$of $1,119 \times 10^{9} / \mathrm{L}, \mathrm{CD}^{+}$of $2,017 \times 10^{9} / \mathrm{L}, \mathrm{CD} 19^{+}$of $487 \times$ $10^{9} / \mathrm{L}$, and $\mathrm{CD}^{+} 6^{+}$of $2 \times 10^{9} / \mathrm{L}$. Further immunological studies by fluorescence-activated cell sorting revealed normal fresh degranulation of natural killer cells (14.7\%; normal: $>10 \%$ ), and normal expressions of perforin, CD27, SAP, and XIAP on d 7. Microscopy of the patient's hairs showed no anomaly of pigmentation, as would be found in children with Griscelli syndrome.

The patient was further evaluated with cultures of blood, urine, tracheal secretion, and stool. Examinations for ova or parasites provided negative results. All serological and PCR tests for viruses (Epstein-Barr, human immunodeficiency, cytomegaly, hanta, adeno, influenza a/b, respiratory syncytial, herpes simplex, corona, metapneumonia, parvo B19, parainfluenza, rhino, and enterovirus) were negative. Also negative were results of testing for leishmania, legionella, aspergillus, Pneumocystis jirovecii, Hemophilus influenza b, and pneumococcus-PCR/ immunoglobulins (IgG/IgM).

All tumors markers $\alpha$-fetoprotein $(2.5 \mathrm{IU} / \mathrm{mL})$, neuronspecific enolase $(10 \mathrm{ng} / \mathrm{mL}), \beta$-hCG $(0.2 \mathrm{mIU} / \mathrm{mL})$, homovanillic acid (10 mg/g creatinine), and vanillylmandelic acid $(18 \mathrm{mg} / \mathrm{g}$ creatinine) were unrevealing. 


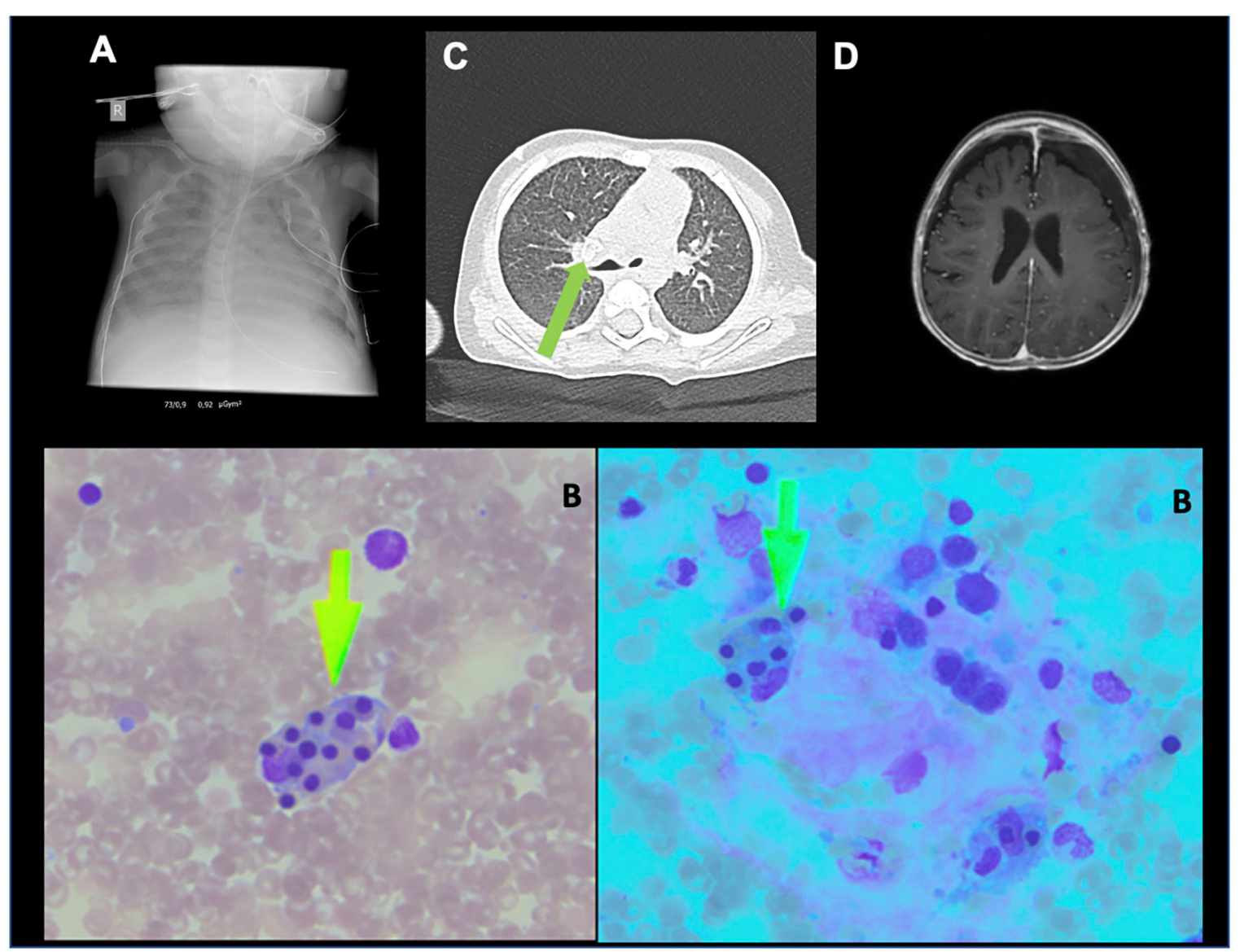

FIGURE 1 | (A) patient's chest X-ray ad admission with acute respiratory distress syndrome, (B) bone arrow smear (Pappenheim stain) with hemophagocytosis (arrow), (C) patient's CT-scan after ECMO (day 30): calcified lymph node (arrow), (D) patient's MRI-scan after ECMO (day 42 ): small hygroma and CNS-miliary tuberculosis.

A positive result from the interferon-gamma release assay (IGRA) was the first indication for possible TBC infection on d 12. However, microscopy for acid-fast bacilli (ZiehlNeelsen stain) as well as PCR testing for TBC in the first bronchoalveolar lavage were both negative on $\mathrm{d}$ 6. Further along in the clinical course, PCR for TBC became positive and the bronchoalveolar lavage fluid culture returned positive results on $\mathrm{d} 40$. The identified strain of $M$. tuberculosis was found to be sensitive to rifampicin, ethambutol, pyrazinamide, and isoniazid, retrospectively.

After discontinuation of the ECMO therapy, further imaging was performed. Magnetic resonance imaging of the central nervous system showed a miliary $\mathrm{TBC}$ and a computed tomography scan of the thorax revealed a calcified, round lesion consistent with TBC (Figures 1C,D).

Normal functional assays virtually excluded hereditary forms of HLH. A secondary form was therefore recommended to be considered, as was a complete diagnostic re-evaluation (infection, tumor, leukemia). The etoposide (VP-16, according to the HLH04 protocol) was terminated after three doses administered according the HLH protocol.

\section{Treatment}

The child presented with severe hypoxia, and respiratory and metabolic acidosis, despite pressure-controlled ventilation and attempts of high frequency oscillation ventilation, both at high inspiratory oxygen level. The decision was therefore made to start veno-venous ECMO immediately after admission of the patient (see Figure 2). A 16F Avalon double-lumen cannula (Getinge AB, Gothenburg, Sweden) was inserted in the right internal jugular vein. A blood flow of 120 $\mathrm{mL} / \mathrm{kg} / \mathrm{min}$ was established, which was sufficient to achieve a $\mathrm{PaO}_{2}$ between 85 and $95 \mathrm{mmHg}$, and a $\mathrm{PaCO}_{2}$ between 40 and $50 \mathrm{mmHg}$. Ventilator parameters were reduced as much as possible (peak inspiratory pressure of $16 \mathrm{~cm}$ $\mathrm{H}_{2} \mathrm{O}$, positive end-expiratory pressure of $6 \mathrm{~cm} \mathrm{H}_{2} \mathrm{O}$, and $\mathrm{FiO}_{2}$ of 0.4) to guarantee "lung protection" as well as a transcutaneous $\mathrm{O}_{2}$-saturation of $>90 \%$. After initiation of the ECMO catecholamine support with epinephrine and noradrenaline (maximum dosage of $0.18 \mu \mathrm{g} / \mathrm{kg} / \mathrm{min}$ ) was progressively weaned (until d 12).

Because of the fulfillment of criteria for HLH therapy, the HLH-94 protocol was initiated. The boy was treated 

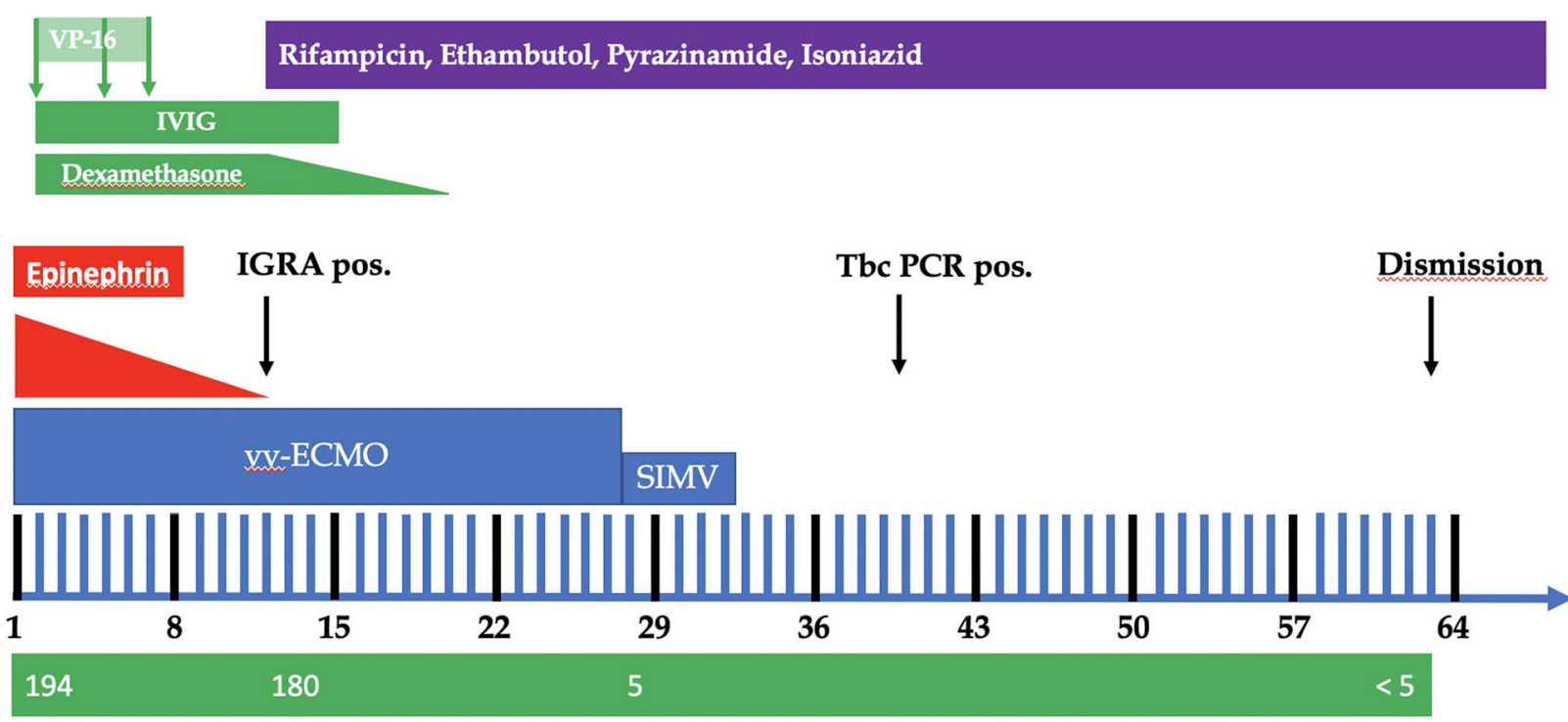

C-Reactive Protein ( $\mathrm{mg} / \mathrm{l}$ )

Time after admission (days)

FIGURE 2 | Course of the patient.

with dexamethasone at $10 \mathrm{mg} / \mathrm{m}^{2}$ (d 2 to $\mathrm{d} 12$, and reduced/discontinued at $\mathrm{d} 24$ ) and etoposide at $150 \mathrm{mg} / \mathrm{m}^{2}$ (three doses in total, given on $\mathrm{d} 2$ through $\mathrm{d} 7$ and being stopped upon normal results from the $\mathrm{T}$ cell degranulation assay on $\mathrm{d}$ 7). Additionally, intravenous immunoglobulin $(0.5 \mathrm{~g} / \mathrm{kg}$ body weight, given on d 2 through d 15) was administered.

With the suspicion of TBC, on d 12 (positive IRGA) a 4-fold tuberculostatic therapy was started, consisting of rifampicin at $1 \times 15 \mathrm{mg} / \mathrm{kg}$ body weight $/ \mathrm{d}$, ethambutol at $1 \times 30 \mathrm{mg} / \mathrm{kg}$ body weight/d, pyrazinamide at $1 \times 30 \mathrm{mg} / \mathrm{kg}$ body weight/d, and isoniazid $1 \times 10 \mathrm{mg} / \mathrm{kg}$ body weight/d). At $10 \mathrm{~d}$ after the start of tuberculostatic therapy, there was improvement in the general condition (stable cardiorespiratory situation, rising tidal volumes). The C-reactive protein level declined from $194 \mathrm{mg} / \mathrm{L}$ to $5 \mathrm{mg} / \mathrm{L}$ on $\mathrm{d} 28$, followed by the soluble interleukin-2 receptor from $30,247 \mathrm{U} / \mathrm{mL}$ to $931 \mathrm{U} / \mathrm{mL}$ on $\mathrm{d} 40$. After full lung recovery, the ECMO support was able to be discontinued on $\mathrm{d} 28$. The child was extubated on $\mathrm{d} 33$.

\section{Outcome and Follow-Up}

The boy survived this critical condition. After discharge on $\mathrm{d} 66$, the child was re-evaluated on d 98, d 460, and d 745. During that time, the boy developed frontotemporal hygroma (left side $>$ right side) with spontaneous resolution. Neurological assessment during the follow-up period revealed a mild retardation of development (speech and fine motor skills) and moderate aggressive behavior with beginning improvement.

\section{DISCUSSION}

This case report shows a rare combination of two so-called "mimickers." TBC is known as a "great mimicker" (4) but HLH can also be mistaken as sepsis (5-7). The HLH syndrome is characterized by an inadequate immune response, with proliferation and activation of macrophages that leads to an exorbitant phagocytosis of hematologic precursors and erythrocytes, platelets, etc. (8). It can occur as a primary disorder (F-HLH) caused by different genetic mutations [i.e., PRF, UNC13D, STXBP2, STX11, and RAB27A (9)], or as a secondary sporadic disorder triggered by infection, autoimmune diseases, pregnancy, or malignant diseases (Table 1) (10-37, 46-49). In our case, the young age and the massive involvement of the lung, the high activity of the disease (high laboratory values for ferritin and the surface interleukin-2 receptor) led us to the suspicion of primary, hereditary HLH. The cytotoxic drug etoposide (VP-16, a semisynthetic derivative of podophyllotoxin) was therefore started, according the HLH-94 protocol, after informed consent was obtained from the parents (50). In the same period, degranulation assays were carried out to verify the suspicion of hereditary HLH. Familial forms of HLH are identifiable by functional immunological tests (natural killer cell and cytotoxic T lymphocyte degranulation, and expression of perforin, SAP, and XIAP), allowing a rapid and reliable classification of affected patients (51). After exclusion of hereditary HLH on d 7, the VP-16 was stopped to avoid its side effects, such as bone marrow suppression or secondary infection. It was very important for us to diagnose or exclude f-HLH because of the cytostatic treatment. Not only were expression of perforin (FHL2), CD27, SAP (XLP1), and XIAP (XLP2) determined to be normal. Also NK cell degranulation assays were performed with normal results to exclude further cytotoxicity defects which do include Munc13-4 (FHL3), STX11 (FHL4), Munc18-2 (FHL5), RAB27A (GS2), LYST (CHS). These fully normal test virtually exclude these deficiencies, which is why-following a well-established diagnostic algorithm-genetic testing was not required. 
TABLE 1 | Causes of sporadic forms of HLH.

\begin{tabular}{|c|c|c|c|c|c|}
\hline \multicolumn{4}{|c|}{ Infectious agents } & \multirow[t]{2}{*}{ Malignancy } & \multirow[t]{2}{*}{ Others } \\
\hline Viral & Bacterial & Fungal & Parasitic & & \\
\hline Adenovirus (10) & $\begin{array}{l}\text { Hemophilus } \\
\text { influenza (11) }\end{array}$ & $\begin{array}{l}\text { Candida albicans } \\
\text { (12) }\end{array}$ & Leishmania (13) & $\begin{array}{l}\text { Non-Hodgkin } \\
\text { lymphoma (14) }\end{array}$ & MDS (15) \\
\hline $\begin{array}{l}\text { Cytomegalovirus } \\
\text { (16) }\end{array}$ & $\begin{array}{l}\text { Mycoplasma } \\
\text { pneumoniae (17) }\end{array}$ & $\begin{array}{l}\text { Cryptococcus } \\
\text { neoformans (18) }\end{array}$ & $\begin{array}{l}\text { Plasmodium spp. } \\
\text { (19) }\end{array}$ & $\begin{array}{l}\text { Acute } \\
\text { lymphoblastic } \\
\text { leukemia (20) }\end{array}$ & Pregnancy (21) \\
\hline $\begin{array}{l}\text { Epstein-Barr virus } \\
\text { (22) }\end{array}$ & $\begin{array}{l}\text { Staphylococcus } \\
\text { spp. (23) }\end{array}$ & $\begin{array}{l}\text { Histoplasma } \\
\text { capsulatum (24) }\end{array}$ & & $\begin{array}{l}\text { Hodgkin's disease } \\
\text { (25) }\end{array}$ & $\begin{array}{l}\text { Rheumatic } \\
\text { diseases }(26,27)\end{array}$ \\
\hline Enterovirus (28) & $\begin{array}{l}\text { Streptococcus } \\
\text { spp. (29) }\end{array}$ & $\begin{array}{l}\text { Fusarium } \\
\text { oxysporum (30) }\end{array}$ & & $\begin{array}{l}\text { Acute myeloid } \\
\text { leukemia (31) }\end{array}$ & \\
\hline $\begin{array}{l}\text { Herpes simplex } \\
\text { virus (32) }\end{array}$ & $\begin{array}{l}\text { Brucella } \\
\text { spp. (33) }\end{array}$ & & & $\begin{array}{l}\text { Chronic lymphatic } \\
\text { leukemia (34) }\end{array}$ & \\
\hline $\begin{array}{l}\text { Human } \\
\text { immunodeficiency } \\
\text { virus (35) }\end{array}$ & Coxiella spp. (36) & & & & \\
\hline Influenza virus (37) & $\begin{array}{l}\text { Mycobacterium } \\
\text { tuberculosis } \\
(38-45)\end{array}$ & & & & \\
\hline $\begin{array}{l}\text { Parvovirus B19 } \\
\text { (46) }\end{array}$ & $\begin{array}{l}\text { Mycobacteria } \\
\text { other than TBC, } \\
\text { MOTT (47) }\end{array}$ & & & & \\
\hline \multicolumn{6}{|l|}{ Varicella virus (48) } \\
\hline Measles virus (49) & & & & & \\
\hline
\end{tabular}

HLH, hemophagocytic lymphohistiocytosis, MDS, myelodysplastic syndrome; MOTT, mycobacteria other than tuberculosis.

Reports in the literature argue the pros and cons of chemotherapy for treatment of secondary HLH. Fatal outcomes after usage of chemotherapy have been reported for cases of Epstein-Barr virus-associated HLH (52). On the other hand, one report showed chemotherapy to be beneficial, even with pregnancy-associated HLH (53). Thus, the use of VP-16 remains a case-by-case decision, based upon weighing up the severity of the disease with the possible side effects.

The limitation of this report is that TBC is known to trigger secondary HLH. We found 8 other cases with TBC and HLH in neonates and infants (38-45) (Table 2) but none of them need ECMO-support. Most of these patients presented with respiratory failure. Half of them received a specific treatment for HLH (e.g., immunoglobulins, dexamethasone). In 7 of the 8 cases, TBC was diagnosed in a timely manner, and the appropriate tuberculostatic therapy was started. From these reports, however, survival seemed to be more related to the TBC treatment than to the HLH treatment. In our case, the ECMO support guaranteed immediate survival, buying time to identify the underlying disease, to initiate a specific treatment, and to promote healing. Without these (pre-)conditions, ECMO therapy has no purpose (per se) and is very probably futile. We conclude, that even though diagnosis and treatment of TBCassociated HLH is difficult and outcome is uncertain, ECMO support should not be withheld from these very sick patients. Disorders of Mendelian Susceptibility to Mycobacterial Disease predominantly predispose to non-tuberculous mycobacteria and were thus not further investigated. The fact that the patient has remained well and asymptomatic for $>4$ years, underscores that HLH was of secondary nature and no predisposition syndrome is present.
Diagnosing TBC in neonates, infants, and young children remains problematic, since false negative results are common. In our case, microscopy for acid-fast bacilli as well as the initial PCR for TBC were both negative. In contrast, the IRGA-test surprisingly returned positive. Because of the published limitations of the IRGA in children $<5$ years old (54), the intracutaneous skin test is still usually recommended. In most of the 8 reported cases, the TBC was diagnosed by microscopy or PCR. However, recent data suggest that the IRGA may have a role in diagnosing TBC in infants as well (55). In our case, tuberculostatic therapy was initiated on suspicion. The definite diagnosis of TBC was achieved by positive cultures, with a duration of $5 \mathrm{wk}$. Later, there was further radiological evidence of miliary lesions in the lungs, central nervous system, and lymph nodes.

\section{CONCLUSION}

Few cases of TBC-associated HLH in neonates and infants are reported in the literature. Due to the high incidence of TBC in India, most of these reports originate from that country (56). However, even in high-income countries, physicians should be aware of the risk and the symptoms of TBC, which may present as severe illness in infancy, with signs of $\mathrm{HLH}$ and acute respiratory failure. Treatment for TBC may be started on suspicion to avoid loss of time. HLH should also be addressed specifically. In the case of refractory hypoxemia, application of ECMO meanwhile can support and bridge the patient until the specific therapy can be effective. 
TABLE 2 | Published cases of TBC-induced HLH in neonatal age or infancy.

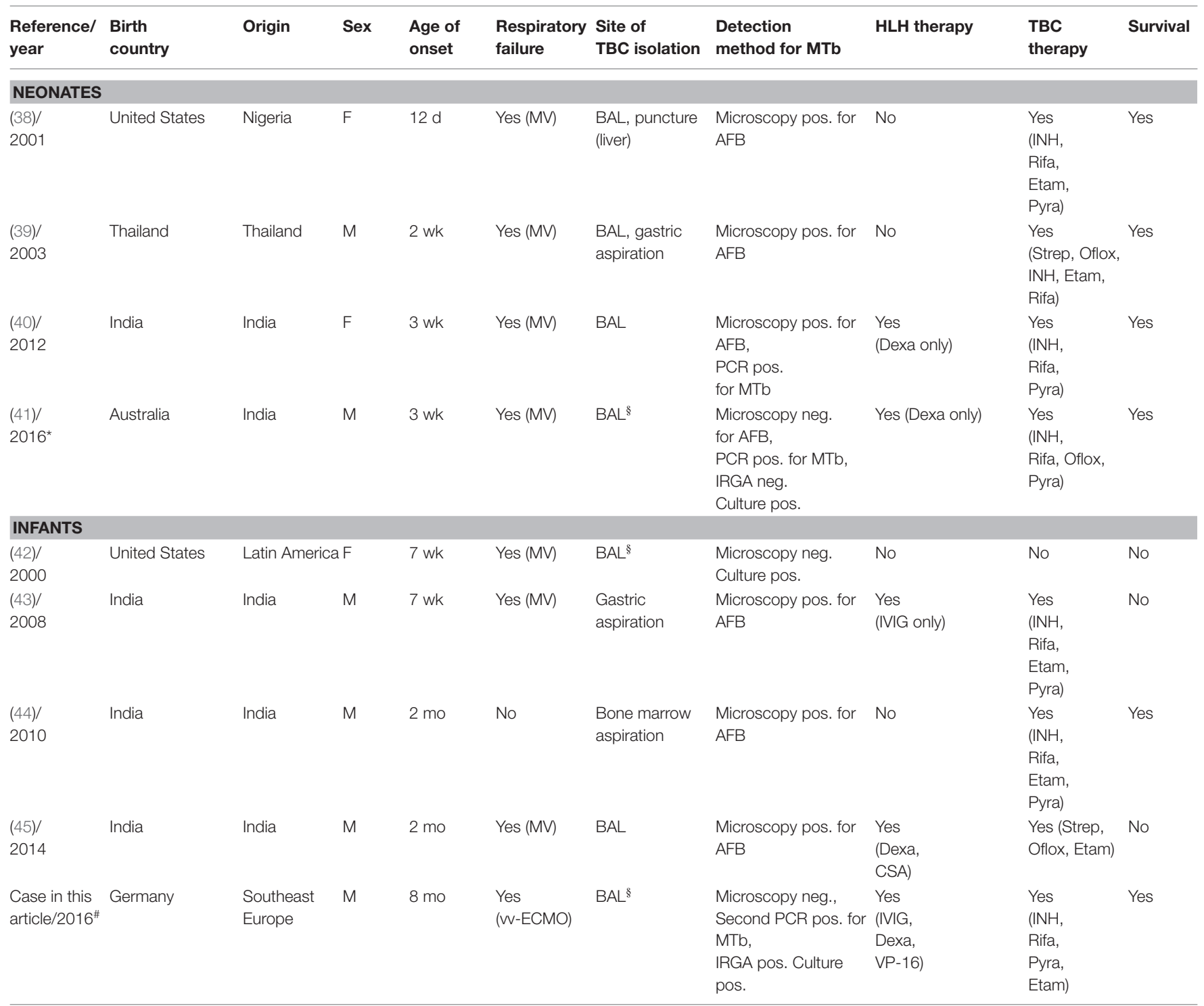

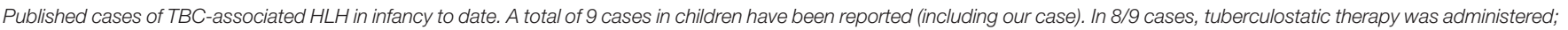
in 5/9 cases, HLH-therapy was administrated. At total of 3 children died, 2 of whom were treated with HLH therapy and tuberculostatic therapy.

\# Year of appearance.

"Proven congenital TBC.

$\S$ TBC culture after 5-6 wk.

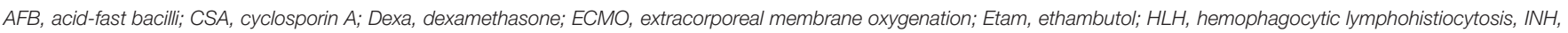

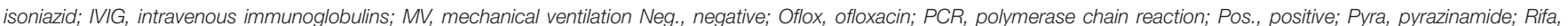
rifampicin; Strep, streptomycin; TBC, tuberculosis; VP-16. etoposide.

\section{DATA AVAILABILITY STATEMENT}

All datasets generated for this study are included in the article/supplementary material.

\section{ETHICS STATEMENT}

Written informed consent was obtained from the minor(s)' legal guardian/next of kin for the publication of any potentially identifiable images or data included in this article.

\section{INFORMED CONSENT STATEMENT}

Informed written consent was obtained from the parents of the patient for publication of this report and any accompanying anonymized images.

\section{CARE CHECKLIST STATEMENT}

The authors have read the CARE Checklist (2013), and the manuscript was prepared and revised according to the CARE Checklist (2013). 


\section{AUTHOR CONTRIBUTIONS}

$\mathrm{HH}$ was the patient's physician, reviewed the literature, and drafted the manuscript. SS, WW, ES, DK, and CN were the patient's physicians, reviewed the literature and contributed to the manuscript's drafting. CJ reviewed

\section{REFERENCES}

1. Janka G, Lehmberg K. Hemophagocytic syndromes-an update. Blood Rev. (2014) 28:135-42. doi: 10.1016/j.blre.2014.03.002

2. Lehmberg K, Nichols KE, Jan-Henter I, Girschikofsky M, Greenwood T, Jordan $\mathrm{M}$, et al. Consensus recommendations for the diagnosis and management of hemophagocytic lymphohistiocytosis associated with malignancies. Haematologica. (2015) 100:9971004. doi: 10.3324/haematol.2015.123562

3. Sen ES, Steward CG, Ramanan AV. Diagnosing haemophagocytic syndrome. Arch Dis Child. (2017) 102:279-84. doi: 10.1136/archdischild-2016-310772

4. Zhang Y, Liang G, Qin H, Li Y, Zeng X. Tuberculosis-associated hemophagocytic lymphohistiocytosis with initial presentation of fever of unknown origin in a general hospital. Medicine (Baltimore). (2017) 96:6575. doi: 10.1097/MD.0000000000006575

5. Casault C, Posadas-Calleja JG. Secondary hemophagocytic lymphohistiocytosis: a challenging diagnosis in a patient with autoimmune hepatitis. Case Rep Crit Care. (2019) 4:3580796. doi: 10.1155/2019/3580796

6. Aryal MR, Badal M, Giri S, Aryal S. Haemophagocytic lymphohistiocytosis mimicking septic shock after the initiation of chemotherapy for squamous cell carcinoma of the neck. BMJ Case Rep. (2013) 2013:bcr2013009651. doi: 10.1136/bcr-2013-009651

7. Rouphael NG, Talati NJ, Vaughan C, Cunningham K, Moreira R, Gould C. Infections associated with haemophagocytic syndrome. Lancet Infect Dis. (2007) 7:814-22. doi: 10.1016/S1473-3099(07)70290-6

8. Filipovich AH, Chandrakasan S. Pathogenesis of hemophagocytic lymphohistiocytosis. Hematol Oncol Clin North Am. (2015) 29:895-902. doi: 10.1016/j.hoc.2015.06.007

9. Cetica V, Sieni E, Pende D, Danesino C, De Fusco C, Locatelli F, et al. Genetic predisposition to hemophagocytic lymphohistiocytosis: report on 500 patients from the Italian registry. J Allergy Clin Immunol. (2016) 137:18896. doi: 10.1016/j.jaci.2015.06.048

10. Censoplano N, Gorga S, Waldeck K, Stillwell T, Rabah-Hammad $\mathrm{R}$, Flori $\mathrm{H}$. Neonatal adenovirus infection complicated by hemophagocytic lymphohistiocytosis syndrome. Pediatrics. (2018) 141: S475-80. doi: 10.1542/peds.2017-2061

11. Kong MS, Engel SH, Zalzal GH, Preciado D. Necrotizing epiglottitis and hemophagocytic lymphohistiocytosis. Int J Pediatr Otorhinolaryngol. (2009) 73:119-25. doi: 10.1016/j.ijporl.2008.09.028

12. Mustafa Ali M, Ruano Mendez AL, Carraway HE. Hemophagocytic lymphohistiocytosis in a patient with Hodgkin lymphoma and concurrent EBV, CMV, and Candida infections. I Investig Med High Impact Case Rep. (2017) 5:2324709616684514. doi: 10.1177/2324709616684514

13. Matnani R, Ganapathi KA. Hemophagocytic lymphohistiocytosis associated with visceral leishmaniasis. Blood. (2016) 127:513. doi: 10.1182/blood-2015-10-678862

14. Li W, Repnikova E. ALK-positive anaplastic large-cell lymphoma with marked leukemoid reaction and hemophagocytic lymphohistiocytosis. Blood. (2016) 127:2041. doi: 10.1182/blood-2016-01-695288

15. Daitoku S, Aoyagi T, Takao S, Tada S, Kuroiwa M. Successful treatment of hemophagocytic lymphohistiocytosis associated with low-risk myelodysplastic syndrome by azacitidine. Intern Med. (2018) 57:2995-9. doi: 10.2169/internalmedicine.0497-17

16. Bonnecaze AK, Willeford WG, Lichstein P, Ohar J. Acute cytomegalovirus (CMV) infection associated with hemophagocytic lymphohistiocytosis (HLH) in an immunocompetent host meeting all eight HLH 2004 diagnostic criteria. Cureus. (2017) 9:e1070. doi: 10.7759/cureus.1070 the literature and contributed to the manuscript's drafting. KL, SE, and CS performed the immunological analyses, and both were responsible for the revision of the manuscript for important intellectual content. All authors issued final approval for the version to be submitted.
17. Yasutomi M, Okazaki S, Hata I, Tanizawa A, Tamamura S, Kawakita M, et al. Cytokine profiles in Mycoplasma pneumoniae infection-associated hemophagocytic lymphohistiocytosis. J Microbiol Immunol Infect. (2016) 49:813-6. doi: 10.1016/j.jmii.2014.11.015

18. Geerdes-Fenge HF, Löbermann M, Hemmer CJ, Benedek O, Reisinger EC. Tuberculosis-associated hemophagocytic lymphohistiocytosis with subsequent unmasking cryptococcal immune reconstitution inflammatory syndrome (IRIS) in an HIV-negative man. Infection. (2019) 47:129-33. doi: 10.1007/s15010-018-1226-1

19. Ullah W, Abdullah HM, Qadir S, Shahzad MA. Haemophagocytic lymphohistiocytosis (HLH): a rare but potentially fatal association with Plasmodium vivax malaria. BMJ Case Rep. (2016) 2016:bcr2016215366. doi: 10.1136/bcr-2016-215366

20. Martínez-Romera I, Villa M, Areal P, Rodrigo E, Herrero B, López-Ibor B. Hemophagocytic lymphohistiocytosis: a dangerous intruder in pediatric acute lymphoblastic leukemia. J Pediatr Hematol Oncol. (2018) 40: e10810. doi: 10.1097/MPH.0000000000000932

21. Kerley RN, Kelly RM, Cahill MR, Kenny LC. Haemophagocytic lymphohistiocytosis presenting as HELLP syndrome: a diagnostic and therapeutic challenge. BMJ Case Rep. (2017). doi: 10.1136/bcr-2017-219516

22. Lai W, Wang Y, Wang J, Wu L, Jin Z, Wang Z. Epstein-Barr virusassociated hemophagocytic lymphohistiocytosis in adults and adolescents-a life-threatening disease: analysis of 133 cases from a single center. Hematology. (2018) 23:810-6. doi: 10.1080/10245332.2018.1491093

23. Xu P, Zeng $\mathrm{H}$, Zhou M, Ouyang J, Chen B, Zhang Q. Successful management of a complicated clinical crisis: a patient with left-sided endocarditis and secondary hemophagocytic lymphohistiocytosis: a rare case report and literature review. Medicine (Baltimore). (2017) 96:e9451. doi: 10.1097/MD.0000000000009451

24. Huang AM. Hemophagocytic lymphohistiocytosis and disseminated histoplasmosis. Blood. (2014) 123:2449. doi: 10.1182/blood-2014-01-550657

25. Hu S, Bansal P, Lynch D, Rojas Hernandez CM, Dayao Z. Rituximab, etoposide, methylprednisolone, high-dose cytarabine, and cisplatin in the treatment of secondary hemophagocytic lymphohistiocytosis with classical Hodgkin lymphoma: a case report and review of the literature. J Med Case Rep. (2016) 10:365. doi: 10.1186/s13256-016-1143-9

26. Sarkar RN, Bhattacharya R, Bhattacharyya K, Paul R, Mullick OS. Adult onset Still's disease with persistent skin lesions complicated by secondary hemophagocytic lymphohistiocytosis. Int J Rheum Dis. (2014) 17:11821. doi: 10.1111/1756-185X.12170

27. Lehmberg K, Pink I, Eulenburg C, Beutel K, Maul-Pavicic A, Janka G. Differentiating macrophage activation syndrome in systemic juvenile idiopathic arthritis from other forms of hemophagocytic lymphohistiocytosis. J Pediatr. (2013) 162:1245-51. doi: 10.1016/j.jpeds.2012.11.081

28. Letsas KP, Filippatos GS, Delimpasi S, Spanakis N, Kounas SP, Efremidis $\mathrm{M}$, et al. Enterovirus-induced fulminant myocarditis and hemophagocytic syndrome. J Infect. (2007) 54:e75-7. doi: 10.1016/j.jinf.2006.04.006

29. Dumancas CY, Reyes HAG, Cosico J, Savadkar A, Lah S. Streptococcus pneumoniae-related hemophagocytic lymphohistiocytosis treated with IVIG and steroids. Am J Case Rep. (2018) 19:25-8. doi: 10.12659/AJCR.906590

30. Albisetti M, Lauener RP, Güngör T, Schär G, Niggli FK, Nadal D. Disseminated Fusarium oxysporum infection in hemophagocytic lymphohistiocytosis. Infection. (2004) 32:364-6. doi: 10.1007/s15010-004-3135-8

31. Hatano K, Nagai T, Matsuyama T, Sakaguchi Y, Fujiwara S, Oh I, et al. Leukemia cells directly phagocytose blood cells in AML-associated hemophagocytic lymphohistiocytosis: a case report and review of the literature. Acta Haematol. (2015) 133:98-100. doi: 10.1159/000360840 
32. Otsubo K, Fukumura A, Hirayama M, Morimoto T, Kato M, Mochizuki H. Hemophagocytic lymphohistiocytosis caused by systemic herpes simplex virus type 1 infection: successful treatment with dexamethasone palmitate. Pediatr Int. (2016) 58:390-3. doi: 10.1111/ped.12817

33. Pekpak E, Sirvan Cetin B. Secondary hemophagocytic lymphohistocytosis in a child with brucellosis. J Pediatr Hematol Oncol. (2017) 39: e5013. doi: 10.1097/MPH.0000000000000849

34. Poole A, Girard N, Clayton F, Tantravahi SK. Rapid onset of hemophagocytic lymphohistiocytosis in a patient with refractory chronic lymphocytic leukemia treated with ibrutinib. Leuk Lymphoma. (2017) 58:1258-61. doi: 10.1080/10428194.2016.1243679

35. Manji F, Wilson E, Mahe E, Gill J, Conly J. Acute HIV infection presenting as hemophagocytic lymphohistiocytosis: case report and review of the literature. BMC Infect Dis. (2017) 17:633. doi: 10.1186/s12879-017-2732-y

36. Harris P, Dixit R, Norton R. Coxiella burnetii causing haemophagocytic syndrome: a rare complication of an unusual pathogen. Infection. (2011) 39:579-82. doi: 10.1007/s15010-011-0142-4

37. Shrestha B, Omran A, Rong P, Wang W. Report of a fatal pediatric case of hemophagocytic lymphohistiocytosis associated with pandemic influenza A (H1N1) infection in 2009. Pediatr Neonatol. (2015) 56:18992. doi: $10.1016 /$ j.pedneo.2013.03.006

38. Akinbami LJ, Selby DM, Slonim AD. Hepatosplenomegaly and pulmonary infiltrates in an infant. J Pediatr. (2001) 139:1249. doi: $10.1067 / \mathrm{mpd} .2001 .115575$

39. Okascharoen C, Nuntnarumit P, Sirinavin S. Neonatal tuberculosis associated with shock, disseminated intravascular coagulation, hemophagocytic syndrome, and hypercalcemia: a case report. J Perinatol. (2003) 23:79-81. doi: 10.1038/sj.jp.7210848

40. Maheshwari P, Chhabra R, Yadav P. Perinatal tuberculosis associated hemophagocytic lymphohistiocytosis. Indian J Pediatr. (2012) 79:12289. doi: 10.1007/s12098-011-0675-7

41. Osowicki J, Wang S, McKenzie C, Marshall C, Gard J, Ke Juin W, et al. Congenital tuberculosis complicated by hemophagocytic lymphohistiocytosis. Pediatr Infect Dis J. (2016) 35:108-10. doi: 10.1097/INF.0000000000000932

42. Shaw PH, Brown D, Shulman ST. Tuberculosis-associated hemophagocytic syndrome in an infant. Pediatr Infect Dis J. (2000) 19:475-7. doi: 10.1097/00006454-200005000-00018

43. Balasubramanian S, Kaarthigeyan K, Aparna V, Srinivas S. Tuberculosisassociated hemophagocytic syndrome in infancy. Indian Pediatr. (2008) 45:593-5.

44. Deshpande A, Nayar PS, Pradhan AM, Manchanda RV. Miliary tuberculosis with hemophagocytosis in a two months old infant. Indian J Hematol Blood Transfus. (2010) 26:115-7. doi: 10.1007/s12288-010-0038-y

45. Dey A, Shah I, Paikrao P, Iyenger V. Tuberculosis with hemophagocytic lymphohistiocytosis in an infant. Indian $J$ Pediatr. (2014) 81:214-5. doi: 10.1007/s12098-013-1022-y

46. Yuan C, Asad-Ur-Rahman F, Abusaada K. A rare case of hemophagocytic lymphohistiocytosis associated with Parvovirus B19 infection. Cureus. (2016) 8:e 897. doi: 10.7759/cureus.897
47. Grandjean Lapierre S, Toro A, Drancourt M. Mycobacterium iranicum bacteremia and hemophagocytic lymphohistiocytosis: a case report. BMC Res Notes. (2017) 10:372. doi: 10.1186/s13104-017-2684-8

48. van der Werff ten Bosch JE, Kollen WJ, Ball LM, Brinkman DM, Vossen AC, Lankester AC, et al. Atypical varicella zoster infection associated with hemophagocytic lymphohistiocytosis. Pediatr Blood Cancer. (2009) 53:2268. doi: $10.1002 /$ pbc. 22041

49. Komatsuda A, Chubachi A, Miura AB. Virus-associated hemophagocytic syndrome due to measles accompanied by acute respiratory failure. Intern Med. (1995) 34:203-6. doi: 10.2169/internalmedicine.34.203

50. Henter JI, Horne A, Aricó M, Egeler RM, Filipovich AH, Imashuku $S$, et al. HLH-2004: diagnostic and therapeutic guidelines for hemophagocytic lympho-histiocytosis. Pediatr Blood Cancer. (2007) 48:124-31. doi: 10.1002/pbc.21039

51. Bryceson YT, Pende D, Maul-Pavicic A, Gilmour KC, Ufheil H, Vraetz $\mathrm{T}$, et al. A prospective evaluation of degranulation assays in the rapid diagnosis of familial hemophagocytic syndromes. Blood 2012 119:275463. doi: 10.1182/blood-2011-08-374199

52. Suma S, Kurita N, Baba N, Ishitsuka K, Sukegawa S, Makishima K, et al. Fatal exacerbations of chronic active Epstein-Barr virus infection subsequent to cytotoxic chemotherapy. Rinsho Ketsueki. (2019) 60:28690. doi: 10.11406/rinketsu.60.286

53. Yue S, Zhao W, Zengping H, Lihong L, Junli L, Hongjun K, et al. Requirement for etoposide in the treatment of pregnancy related hemophagocytic lymphohistiocytosis: a multicenter retrospective study. Orphanet J Rare Dis. (2019) 18:50. doi: 10.1186/s13023-019-1033-5

54. Blandinières A, de Lauzanne A, Guérin-El Khourouj V, Gourgouillon N, See $\mathrm{H}$, Pédron B, et al. QuantiFERON to diagnose infection by Mycobacterium tuberculosis: performance in infants and older children. J Infect. (2013) 67:391-8. doi: 10.1016/j.jinf.2013.06.011

55. Petrucci R, Lombardi G, Corsini I, Bacchi Reggiani ML, Visciotti F, Bernardi F, et al. Quantiferon-TB Gold In-Tube improves tuberculosis diagnosis in children. Pediatr Infect Dis J. (2017) 36:44-9. doi: 10.1097/INF.0000000000001350

56. John TJ, Vashishtha VM, John SM. 50 years of tuberculosis control in India: progress, pitfalls and the way forward. Indian Pediatr. (2013) 50:938. doi: $10.1007 /$ s13312-013-0021-4

Conflict of Interest: The authors declare that the research was conducted in the absence of any commercial or financial relationships that could be construed as a potential conflict of interest.

Copyright (c) 2020 Hauch, Skrzypek, Woessmann, Lehmberg, Ehl, Speckmann, Schneck, Koerholz, Jux and Neuhäuser. This is an open-access article distributed under the terms of the Creative Commons Attribution License (CC BY). The use, distribution or reproduction in other forums is permitted, provided the original author(s) and the copyright owner(s) are credited and that the original publication in this journal is cited, in accordance with accepted academic practice. No use, distribution or reproduction is permitted which does not comply with these terms. 